\title{
Correction to: Relationship Between Dissolved Calcium and Total Calcium in Al-Killed Steels After Calcium Treatment
}

\author{
YANG LIU and LIFENG ZHANG
}

https://doi.org/10.1007/s11663-018-1363-z

(c) The Minerals, Metals \& Materials Society and ASM International 2018

\section{Correction to: Metallurgical and Materials Transactions B https://doi.org/10.1007/s11663-018-1288-6}

THERE are errors in the expression of Eqs. [9] and [11], and Reference 24 in the published article.

Equation [9] should be:

$$
(\mathrm{CaS}) \stackrel{\text { Oxygen }}{\longrightarrow}[\mathrm{Ca}]+[\mathrm{S}]
$$

Equation [11] should be:

$$
[\mathrm{Ca}]+(x+1 / 3)\left(\mathrm{Al}_{2} \mathrm{O}_{3}\right)=\mathrm{CaO} \cdot x \mathrm{Al}_{2} \mathrm{O}_{3}+2 / 3[\mathrm{Al}]
$$

Reference 24 should be:

L. Zhang, Y. Liu, Y. Zhang, Y. Ren, W. Yang, and W. Chen: Metall. Mater. Trans. B, 2018, https://doi.org/ 10.1007/s11663-018-1289-5.

YANG LIU and LIFENG ZHANG are with the School of Metallurgical and Ecological Engineering, University of Science and Technology, Beijing (USTB), Beijing, 100083 P.R. China. Contact e-mail: zhanglifeng@ustb.edu.cn

The original article can be found online at https://doi.org/10.1007/ s11663-018-1288-6.

Article published online July 27, 2018. 